\title{
CHARACTERIZATION OF VARIOUS KINDS OF REFUSED DERIVED FUEL AND THEIR EFFECTS ON CEMENT PROPERTIES
}

Hashem, Fayza, S. ${ }^{(1)}$; Abd.El- Razek, Taha. A. M. ${ }^{(2)}$; Selim, Faten, ${ }^{(1)}$ and Mashhout, $H$.

1) Chemistry Department Faculty of Science, Ain Shams University.2) Basic Science, Institute of Environmental Studies and Research, Ain Shams University

\begin{abstract}
Recently, there is an increasing demand for using refused derived fuels (RDF) as replacement for traditional fossil fuel in energy intensive industries like cement industry. However, using such sources will affect the properties and quality of the produced cement since RDF ash was mixed with OPC clinker during production. In the present study, four solid refused derived fuels namely; rubber waste, tree trimmings, rice straw and municipal solid wastes MSW are characterized and tested as RDF. Also, the effect of their ash on the setting and hardening of the hardened OPC pastes was investigated. Results showed that rubber waste has the highest calorific values followed by MSW. OPC pastes mixed with RDF ash showed reduced setting times. Besides, OPC admixed with rubber wastes ash offered the highest compressive strength values between all the studied RDF sources. Phase composition of the formed hydrates is studied by X-ray diffraction analysis and results showed that the ash within OPC matrix does not change the hydration mechanisms since the same hydration products are formed.

Keywords: Portland cement, Reused drive fuels, rubber Waste, MSW, Energy.
\end{abstract}

\section{INTRODUCTION}

Cement industry has development greatly in the last decades. The aims for such development are resource conservation and environmental protection (Madlool et al., 2011). Cement industry is one of highly energy-intensive 
industry with an energy typically accounting for 30-40 percent of production costs. In traditional cement kilns, different sources of fuels are used such as natural gas, coal and petroleum oil (Singhi and Bhargava, 2010). The fuel mix in the cement kiln is carbon intensive, and the calcination process produce $\mathrm{CO} 2$ gas, so that in total the cement industry contributes by about $5 \%$ of the global CO2 emissions (Martin et al., 1990 and Laszlo et al., 2006). In cement plant, $60 \%$ of the $\mathrm{CO} 2$ emitted results from the calcination of limestone, 30 $\%$ from combustion of fuels in the kiln and 10 per cent from other downstream plant operations (Bosoaga et al., 2009). Refuse Derived Fuel $(\mathrm{RDF})$ is an expression appeared recently in many countries which refers to fuel produced from incineration of solid wastes (Alter et al., 1974) or to obtain energy from waste materials. Waste derived fuels include residues from municipal solid waste (MSW), industrial/ trade waste, sewage sludge, industrial hazardous waste and biomass waste. Most of these wastes are primarily composed of carbon-based organic matter, which releases energy when it reacts, or combusts with oxygen (Seboka et al., 2009). For these, production of RDF does not only eliminate wastes and find a solution to their accumulation but it will also generate energy (Schwarzböck et al., 2016a). Refused derived fuels RDF are increasingly utilized in energy intensive industries such as cement manufacture and steel production (Aldrian et al., 2016). Thereby, RDF could substitute conventional fossil fuels to a large extent since it represents cost saving and usually goes with lower $\mathrm{CO} 2$ emission (Choy et al., 2004 and Marland et al., 2008). In 2006, many European countries already more than $70 \%$ of the overall energy consumption 
of cement manufactures is covered by RDF (Garg et al., 2009).

The main parameters on which solid waste could be chosen as RDF are its higher heating value (energy input), ash residue and the toxicity of the gas evolved. Some researchers have focused on emissions and pollution due to waste derived fuel combustion in cement kilns (Karstensen, 2008) and Zemba et al., 2011). Impacts on the product quality have also been investigated by some authors. When burning RDF, or any kind of waste, the two main byproducts produced are gases and ash. During the burning process in the incinerator many of the pollutants from the exhaust gases could be removed and concentrated in the ash (Guo and Eckert, 1996 and Chatziaras et al., 2014). Consequently, the ash represents a cocktail of toxins; all the pollutants captured at various stages end up here. There are two types of ash: heavy bottom ash, which comes from the furnace where the waste is burnt and light fly ash, which comes from the air pollution control equipment. Numerous studies have confirmed that a typical waste incinerator releases dioxins, lead, cadmium, mercury, and fine particles into the atmosphere (Karstensen, 2008 and Zemba et al., 2011). According to the United States Environmental Protection Agency, municipal waste incinerators are one of the top four sources of dioxin and furan emissions in the USA. Heavy metals are also a major source of environmental concern (Guo and Eckert, 1996). Since these toxins are not destroyed during incineration, they end up in the incinerator ash, or they escape into the environment through the smoke stack and are transported through the air and deposited in water and soil. Recently many countries tend to use RDF as a source of energy in cement industry instead of fossil fuel or as a fraction of the fuel used in the production of cement clinker 
(Kaantee et al., 2004). Industry argues that the use of waste as alternative fuels has several positive impacts on sustainability, i.e. conservation of nonrenewable energy sources, better energy recovery in waste, etc. In addition, the use of alternative fuels can help to reduce the costs of cement production. However this will have a large impact on the quality of clinker produced. Many reports showed that there is a rise in $\mathrm{Cl}-, \mathrm{Pb}, \mathrm{Cd}, \mathrm{Cu}$ and $\mathrm{Zn}$ levels by about 2 to $5 \%$ higher than the clinker produced without using RDF (Gendebien, et al., 2003). Chlorine and phosphate content in waste are important as these can affect cement quality.

The present work aims evaluating four types of solid wastes as an alternative RDF sources. This is done via studying the caloric value and ash residues of these wastes. Beside the effect of their ash residue on the properties of Ordinary Portland cement clinker and the hydration characteristics of the produced hardened OPC pastes are also investigated.

\section{MATERAILS AND EXPERIMENTAL}

Materials: Industrial clinker supplied from Helwan Company for cement production, Helwan, Egypt. It is used for the production of ordinary type I Portland cement (OPC-I, 42.5N). Four wastes include Tree trimmings (TT), Rubber waste (RW), Rice straw (RS) and municipal solid waste (MSW) are collected from local areas and used as an example of RDF. Solid wastes are burned at $1000^{\circ} \mathrm{C}$ for three hours and their ashes are collected and used as additive to OPC clinker. 
Preparation of Dry Mixes: During the grinding of OPC clinker, the ash residues obtained from burning of various RDF wastes under investigation was added to OPC clinker with two percentage composition of 5 and $10 \%$ from the mass of OPC clinker. A constant 5\% of gypsum by weight of clinker has been added to each cement mixture.

Specimen Preparation; Curing and Testing: Different cement pastes were prepared using water/solid $(\mathrm{W} / \mathrm{S})$ ratio $=0.3$. Each paste was prepared by mixing the dry mix with the required amount of water for about three minutes. After complete mixing, the resultant paste was molded into cubic specimens by using one inch cube molds. The molds, containing the pastes, were cured under $100 \%$ relative humidity for 24 hours to attain the final setting, and then the cubic specimens were removed from the molds and cured under water for time intervals of 3, 7 and 28 days.

Compressive Strength: At each time interval, the compressive strength test was performed on three cubes represented each hardened cement paste and the average value was recorded. The hydration of the hardened cement pastes was stopped using the method described in earlier publication (Abo-El-Enein et al., 1972). The samples were then dried at $100^{\circ} \mathrm{C}$ for three hours in $\mathrm{CO}_{2^{-}}$ free atmosphere and conserved in a desiccator containing soda lime and $\mathrm{CaCl}_{2}$ till using for testing purposes.

Hydration Kineticcs: Hydration kinetics was studied by the determination of setting times; chemically combined water and free lime contents at different ages of hydration. 
Setting Time: Setting times determined Using VICAT device .after mixing the cement with the required amount of water which was tested by the penetration of the device plunger in the paste till $4 \mathrm{~mm}$ then after suitable time testing the penetration of the needle in the paste till $4 \mathrm{~mm}$ and at that time recording the initial setting time .after some times starting testing with final setting time needle till only marking the paste surface not penetrate it.

Chemicaly Combined Water: Chemically combined water contents (Wn, $\%)$ were determined as follow (Kondo et al., 1975) :

Two representative samples of the dried specimens, exact about $1 \mathrm{~g}$ each, were weighted in porcelain crucibles and ignited for one hour at $1000^{\circ} \mathrm{C}$ in an adjustable muffle furnace, cooled in a desiccator and then weighted. The chemically-combined water content (i.e., the amount of water retained after drying) was calculated as $\mathrm{Wn}(\%)$ using the following equation:

$\mathrm{Wn}(\%)=\left[\left(\mathrm{W} 1-\mathrm{W}_{2}\right) / \mathrm{W}_{2}\right] \times 100$

$\mathrm{W}_{1}$ : is the weight of the dried sample before ignition $(\mathrm{g})$ and

$\mathrm{W}_{2}$ : is the ignited weight of sample $(\mathrm{g})$.

Free Lime Content (Cao): The free $\mathrm{CaO}$ content was determined by the following method (Abo-El-Enein et al., 1974):The sample (exact about $0.5 \mathrm{~g}$ ) was dispersed in $40 \mathrm{ml}$ of glycerol/ethanol mixture (1:5) by volume; together with small amount of anhydrous barium chloride (about $0.5 \mathrm{~g}$ ) as catalyst, and phenol phethalein as indicator. This mixture was kept in a conical flask, fitted with an air - reflux, on a hot plate for 30 minutes (the color becomes pink). The contents were titrated with a standardized alcoholic ammonium acetate solution until the pink color was disappeared. Heat again, if the pink color 
reappears, complete the titration with ammonium acetate solution until no further appearance of pink color takes place.

Phase Comostion: The phase composition of the formed hydrates was investigated using X-ray diffraction analysis using a cobalt target $(\lambda=0.17889$ $\mathrm{nm}$ ) and a nickel filter under working conditions of $40 \mathrm{kV}$ and $30 \mathrm{~mA}$.

\section{RESULTS AND DISCUSSION}

Table (1): The chemical oxide composition of OPC clinker and the four RDF ashes-clinker mix

\begin{tabular}{|c|c|c|c|c|c|}
\hline oxide & Clinker & TT10\% & RW 10\% & RS 10\% & MSW 10\% \\
\hline \hline $\mathrm{SiO} 2$ & 21.076 & 23.33 & 19.53 & 21.99 & 24.43 \\
\hline $\mathrm{A} 2 \mathrm{O} 3$ & 5.21 & 5.66 & 4.86 & 5.01 & 5.01 \\
\hline $\mathrm{Fe} 2 \mathrm{O} 3$ & 3.43 & 3.83 & 3.21 & 3.2 & 3.73 \\
\hline $\mathrm{CaO}$ & 67.15 & 59.39 & 64.03 & 61 & 58.66 \\
\hline $\mathrm{MgO}$ & 1.96 & 1.9 & 1.76 & 1.93 & 1.91 \\
\hline $\mathrm{K} 2 \mathrm{O}$ & 0.04 & 0.33 & 0.06 & 0.5 & 0.17 \\
\hline $\mathrm{SO} 3$ & 0.31 & 2 & 3.05 & 2.53 & 2.19 \\
\hline $\mathrm{Na} 2 \mathrm{O}$ & 0.36 & 0.33 & 0.35 & 0.46 & 0.4 \\
\hline $\mathrm{LOI}$ & 0.34 & 2.35 & 2.8 & 2.36 & 2.74 \\
\hline
\end{tabular}

Characterization of RDF And RDF ASH: Characterization of RDF and their residues after burning are important parameters to predict the suitability and toxicity of used wastes as RDF sources. In other word, determine their efficiency as fuel and if those sources are/or are not environmental friendly. Beside determination of the percentage of the remained ash for these wastes show how the produces OPC could be affected by these new fuel sources.

Table (2) shows CHN percent, Chloride and sulfur contents, the ash percentage, caloric values and the densities of the solid wastes residues remained after burning of various RDF sources at $1000^{\circ} \mathrm{C}$ for $2 \mathrm{hrs}$. 
According to the listed data, the main compositions of the studied wastes are hydrocarbons with minor amine, sulfur and chloride contents. The percentage of Rubber waste (RW) and Tree trimmings (TT) offer the highest CHN and sulfur and chloride contents. This could predict the highest carbon, sulfur and nitrogen oxides emission by using these wastes as source for RDF. After firing, Rubber waste (RW) offered the highest caloric value (CV) (8600 $\mathrm{Cal} / \mathrm{g}$ ). While as, mixed trash (MT) showed about half the caloric value offered by (RW). Both Tree trimmings (TT) and Rice straw (RS) showed comparable caloric values (3174 and $3167 \mathrm{cal} / \mathrm{g}$ respectively) and lower densities. All the solid wastes show high ash percentage after their firing at $1000^{\circ} \mathrm{C}$ for $2 \mathrm{hrs}$ which varies from 19.2 to $27.7 \%$.

Table (2): Characterization of raw RDF .

\begin{tabular}{|c|c|c|c|c|c|c|c|c|}
\hline $\begin{array}{c}\text { Solid } \\
\text { residue }\end{array}$ & $\boldsymbol{\%} \mathbf{C}$ & $\boldsymbol{\% H}$ & $\boldsymbol{\%} \mathbf{N}$ & $\boldsymbol{\% S}$ & $\boldsymbol{\%} \mathbf{C l}$ & $\begin{array}{c}\text { \% } \\
\text { Ash }\end{array}$ & $\begin{array}{c}\text { Density } \\
(\mathbf{g} / \mathbf{c m 3})\end{array}$ & $\begin{array}{c}\text { Caloric } \\
\text { Value } \\
(\mathbf{C a l} / \mathbf{g})\end{array}$ \\
\hline \hline TT & 46.13 & 4.84 & 4.91 & 3.3 & 0.07 & 27.7 & 0.69 & 3174 \\
\hline RW & 56.43 & 8.23 & 6.27 & 6.1 & 1.3 & 19.2 & 1.1 & 8600 \\
\hline RS & 36.99 & 5.25 & 4.35 & 0.3 & 0.03 & 21.3 & 0.35 & 3167 \\
\hline MSW & 26.29 & 4.33 & 3.55 & 0.52 & 0.02 & 22.9 & 0.4 & 4200 \\
\hline
\end{tabular}

Setting Times: Fig. (1a-d) shows the initial and final setting times for Portland cement pastes admixed with 5 and $10 \mathrm{wt}$ \% of RDF ash of various origin. All the OPC pastes admixed with 5 wt. \% of RDF ash showed a reduction of both initial and final setting times compared to OPC paste free of ash, mix B. These reduction of setting times were also observed for OPC samples admixed with $10 \mathrm{wt} \%$ of RDF ash except those admixed with 10 wt.\% of tree trimmings (TT) ash which showed a longer setting times. Short 
setting times means high rates of stiffening and hardening of admixed OPC pastes. It is well established that the setting of cement is a percolation process in which isolated or weakly bound particles are connected together by the formation of hydration products when mixed with water (Bentz, 2008). The higher rate of hydration could be related to two effects occurred due to presence of RDF ash. The first is their filler effects due to their greatest fineness and low densities. Besides, the nucleation effect of the RDF ash particles, so they can act as active centers inside OPC matrix that favors the growth of the hydration products on them leading to acceleration of the hydration reaction (Marzouki, et al., 2013).

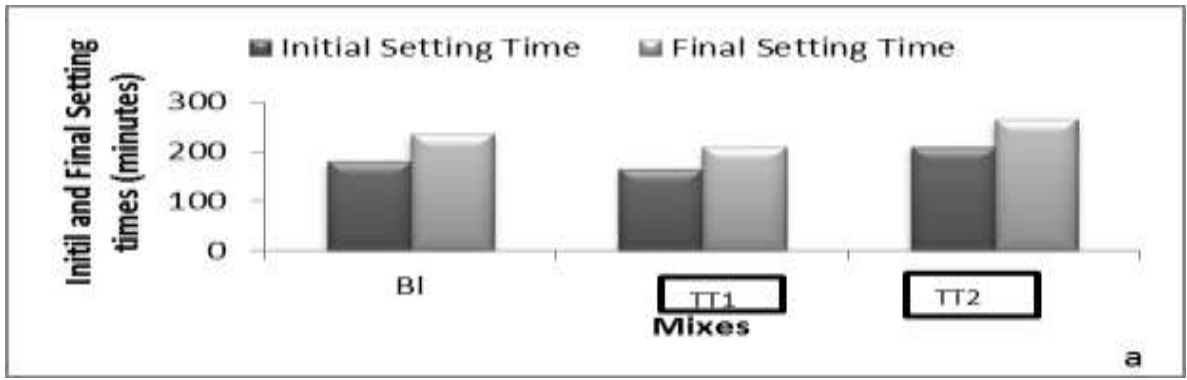

Fig. (1): Initial and final setting times of OPC pastes admixed with RDF ashes, a) tree trimmings; TT1 $5 \%$ ash TT2 10\% ash

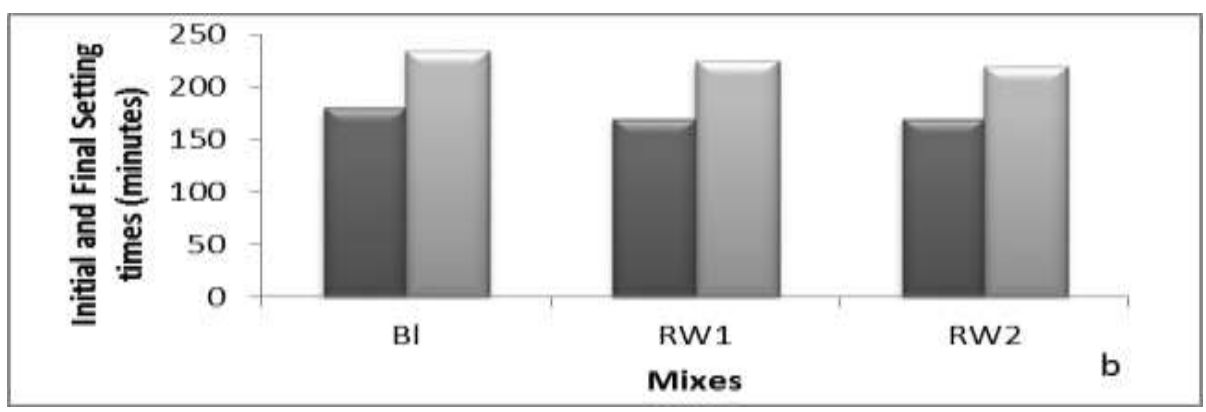

Fig. (2): Initial and final setting times of OPC pastes admixed with RDF ashes b) rubber wastes; RW1 5\% ash RW2 10\% 


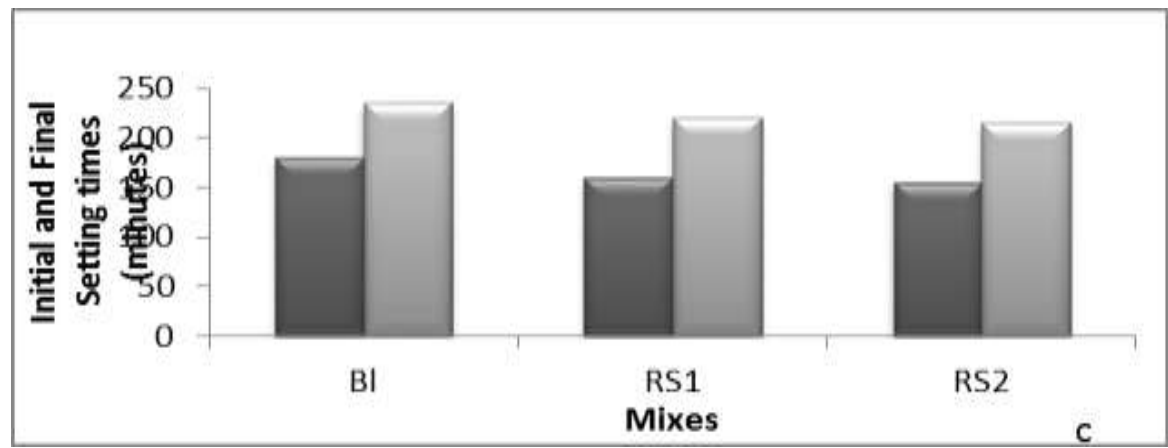

Fig.(3): Initial and final setting times of OPC pastes admixed with RDF ashes c) rice straw; RS1 5\% ash RS2 10\%

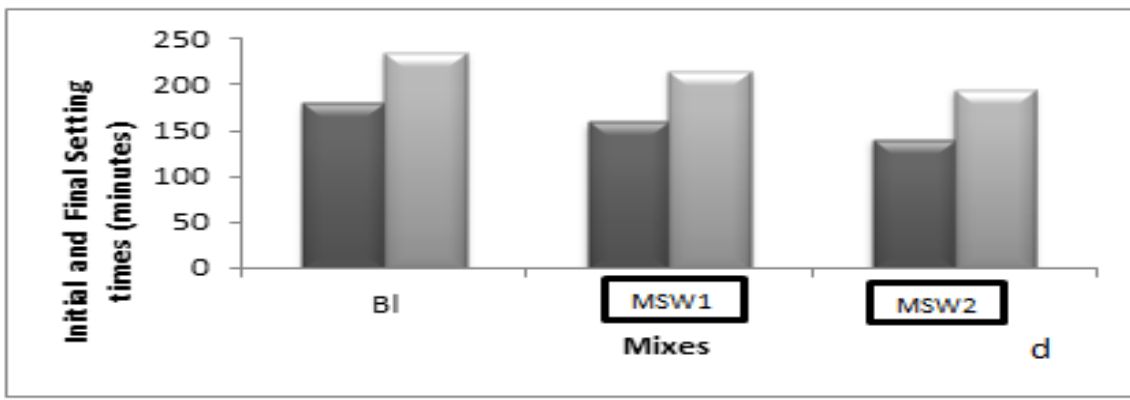

Fig.(4): Initial and final setting times of OPC pastes admixed with RDF ashes, d) municipal solid waste; MSW1 5\% ash MSW2 10\%

COPRESSIVE STRENGTH: The variation of the compressive strength values for OPC and OPC pastes admixed with 5 and 10\% of RDF ash with the hydration ages are shown in Fig. (2 a-d). The control OPC paste, B mix, shows three stages of strength development with increasing the hydration ages up to 90 days. A rapid increase in the compressive strength values is noticed during the first 24 hours of hydration which represent the acceleration stage. This is followed by a continuous and gradual increase up to 28 days which represent the dormant stage. A slow increase in the compressive 68 
strength values noticed during the hydration period from 28 to 90 days which represent the state of equilibrium is reached.

OPC specimens admixed with RDF ash with different origin, showed the same trend of variation of compressive strength values with the hydration ages. However there is a variation in the compressive strength values compared to OPC pastes depending on the hydration period and the origin of RDF ash and its percent in the OPC paste. For OPC pastes admixed with rubber wastes $(5 \& 10 \% \mathrm{RW})$ there is an improvement in the compressive strength values at all hydration ages compared to the control OPC paste (B mix) .In fact these mixes (RW1 and RW2) offered the highest compressive strength values between all the studied RDF sources. Such results are in agreement with the works that using of crushed rubber could improve the OPC and concrete properties (Girskas et al., 2017 and Bisht and Ramana, 2017).

For OPC pastes admixed with other RDF ash (mixes TT, RS and MSW) show higher compressive strength values than blank (neat OPC, mix B) during the early ages of hydration; up to 3 days and sometimes this extended to 7 days as for ash derived from tree trimmings (TT mixes). This confirms that the presences of RDF ash within OPC pastes improve the early hydration reaction as indicated from the setting time results. At later ages of hydration, after 28 and 90 days, the ash admixed OPC pastes show relatively lower or comparable values of the compressive strength to those offered by OPC pastes. Such results are in agreement with those of Katare and Madurwar who used RDF of bio-origin. (Katare and Madurwar, 2017 and Kaminskas et al., 2015). 
OPC pastes admixed with Tree trimmings ash (TT) showed an improvement in the compressive strength values by increasing their percentage in OPC pastes from $5 \mathrm{wt} . \%$ to $10 \mathrm{wt} . \%$. Whiles as both rice straw (RS) and mixed municipal solid waste (MSW) ash showed reverse results.

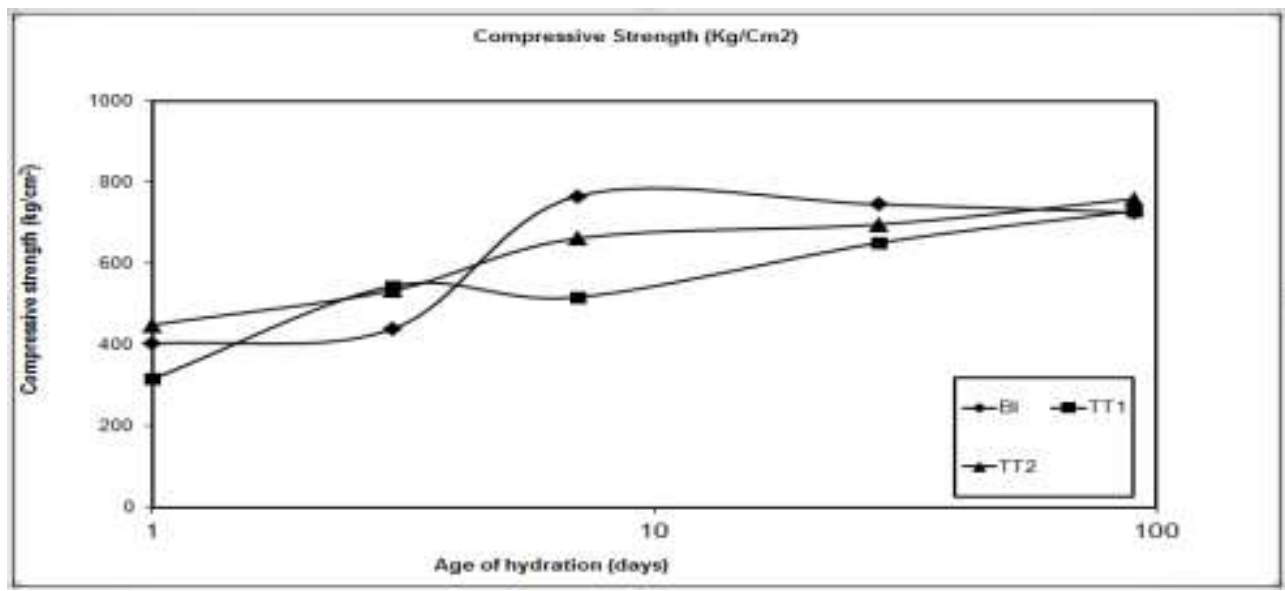

Fig.(2-1): Compressive strength of OPC pastes admixed with RD ashes at various hydration ages; a) tree trimmings; TT1 $5 \%$ ash TT2 10\% ash

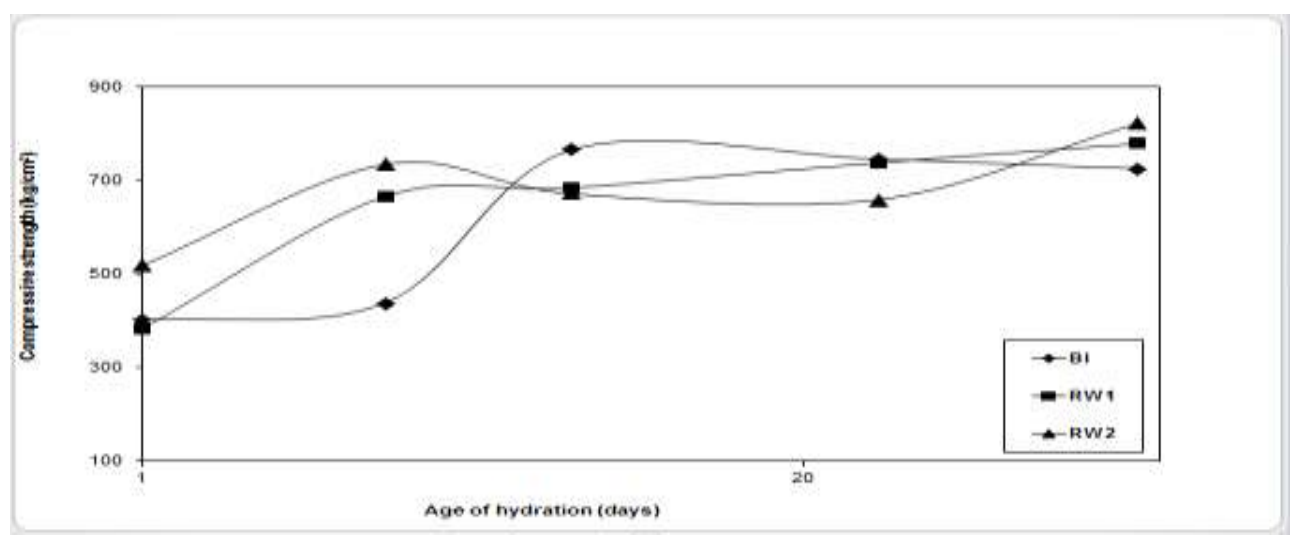

Fig.(2-2): Compressive strength of OPC pastes admixed with RD ashes at various hydration ages; b) rubber wastes; RW1 5\% ash RW2 10\% 


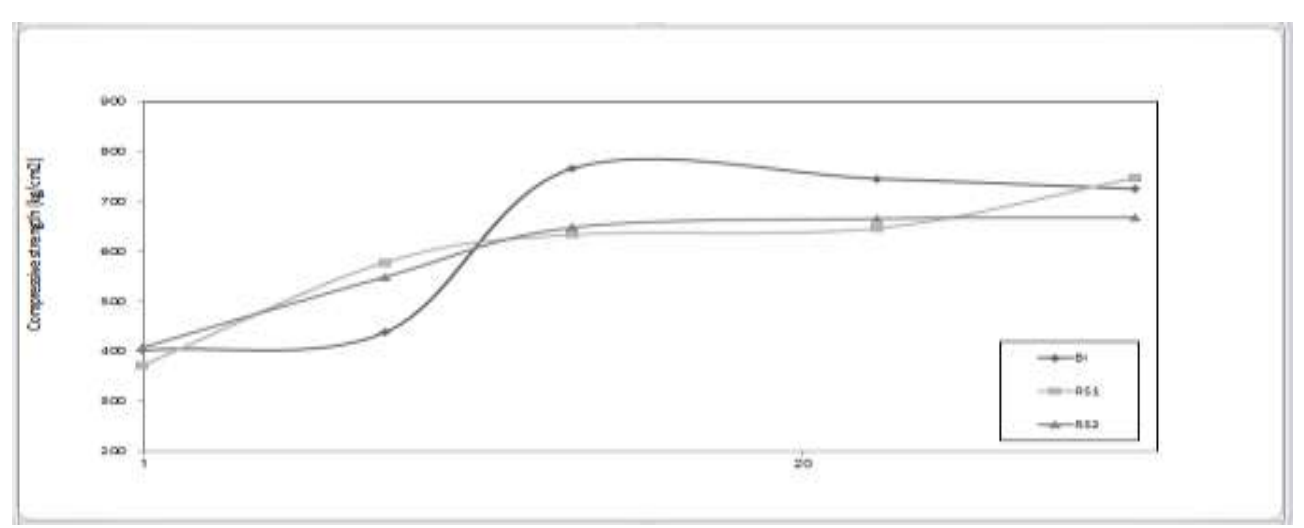

Fig.(2-3): Compressive strength of OPC pastes admixed with RD ashes at various hydration ages; c) rice straw; RS1 5\% ash RS2 10\%

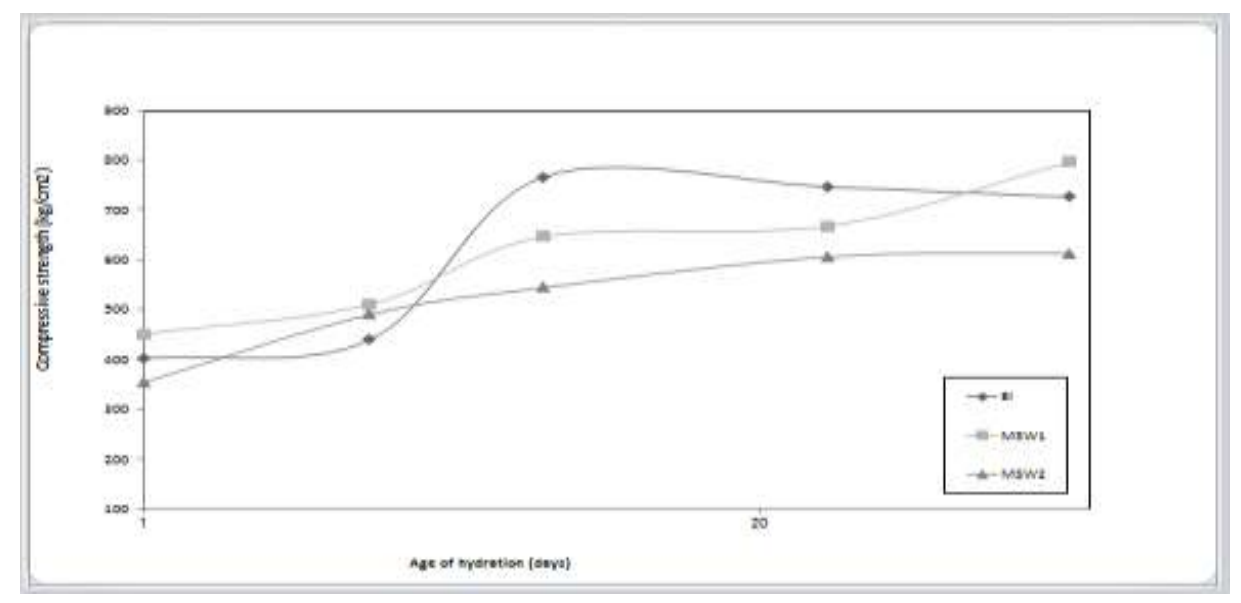

Fig.(2-4): Compressive strength of OPC pastes admixed with RD ashes at various hydration ages d) municipal solid waste; MSW1 5\% ash MSW2 10\%

HYDRATION KINETICS: Hydration kinetics of the investigated pastes was carried out by determining the free lime $(\mathrm{CaO}, \%)$ and chemically combined water (Wn, \%) contents at different ages of hydration. 
COMBINED WATER (Wn \%): The results of non-evaporable (chemically combined) water content, (Wn, \%), obtained for specimens made from neat OPC and those admixed with 5 and 10 wt.\% of RDF ash ( mixes TT, RW, RS and MSW) are represented graphically as a function of hydration age in Figs. $(3,4)$ respectively.

The chemically combined water contents of the hardened specimens made of neat OPC showed three stages of variation of Wn-values with increasing hydration age. An initial stage of rapid increase in Wn values; up to 3 days, which show a fast rate o hydration reaction between water and unhydrated OPC phases ;(El-Gamal et al., (2012). This was followed by a slow stage of increase of Wn value during the period of 3-28 days; this represent the "dormant period" (Morsy et al., (1998). This was followed by an "acceleration stage" with a gradual and continuous increase in the chemically combined water contents with increasing hydration ages up to 90 days. This increase is attributed to the formation and later accumulation of hydration products mainly as $\mathrm{CSH}$.

Obviously, all the OPC mixes admixed with RDF ash showed lower Wn, $\%$ values than the neat OPC mix at all the hydration ages. However such results are in contrary with the setting times and compressive strength results since the admixed mixed showed a reduced setting times and higher strength than the neat OPC. Such finding could be related to the formation of hydration products in OPC-ash mixes with low water contents and improved strength properties (Abo-El-Enein, et al., 2016). 

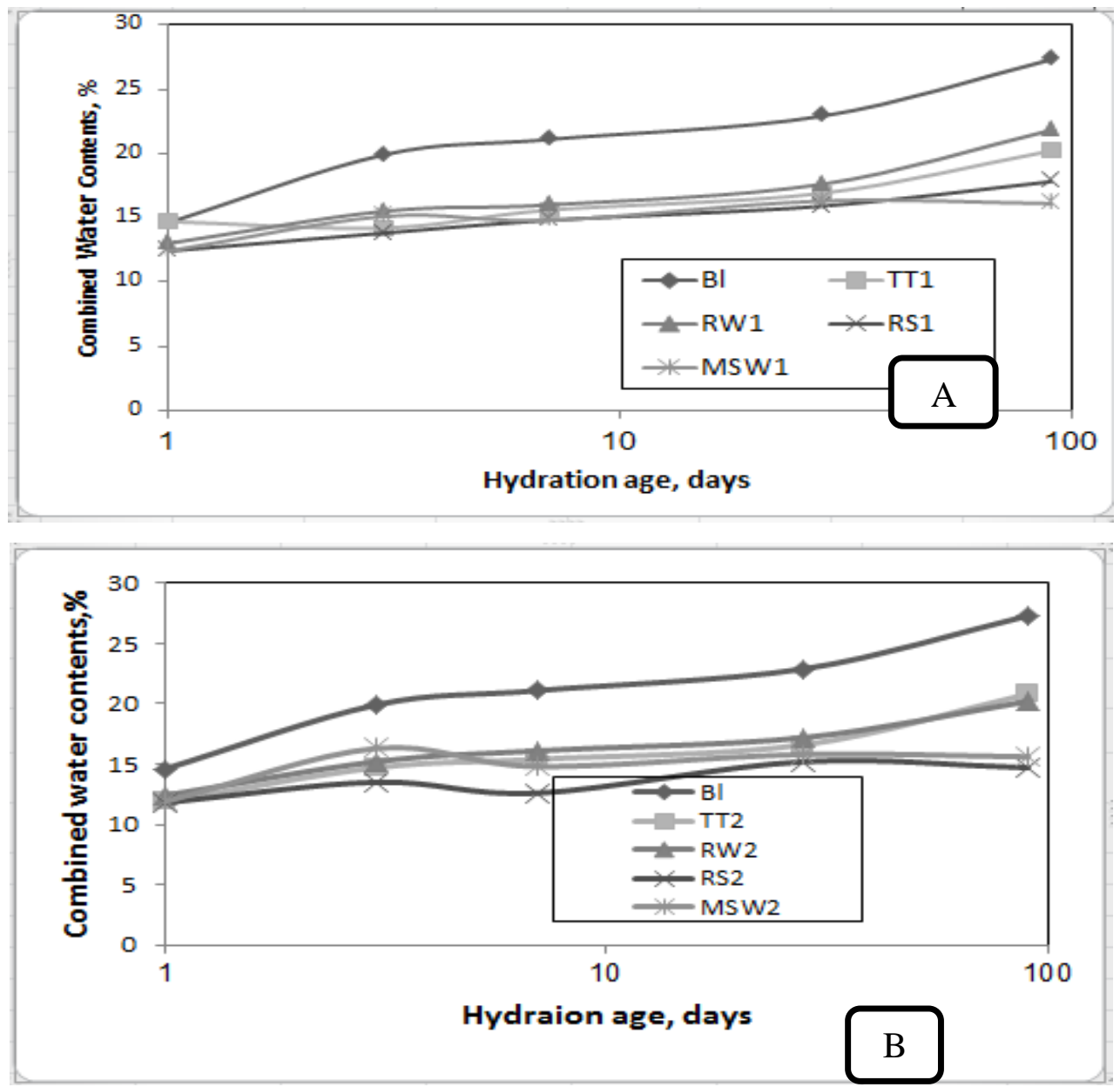

Fig.(5): Combined water contents (\%) o OPC pastes admixed with RD ashes $\begin{array}{ll}\text { a) } 5 \text { wt. } \% & \text { b) } 10 \text { wt. } \%\end{array}$

TT1 5\% ash TT2 10\% ash RW1 5\% ash RW2 10\% RS1 5\% ash RS2 10\% MSW1 5\% ash MSW2 10\%

FREE LIME (CaO): Fig.(4 -a,b) showed the results of the variation in free lime content $(\mathrm{CaO}, \%)$ with age of hydration of the hardened neat OPC pastes, $\mathrm{B}$, and those made of admixing OPC with RDF ash. Obviously, B mix 
showed a gradual and continues increase in free lime contents up to 90 days indicating the progress of the hydration reaction and accumulation of $\mathrm{Ca}$ $(\mathrm{OH})_{2}$ which is one of the hydration products of OPC pastes beside calcium silicate hydrates $\mathrm{CSH}$. For OPC- ash mixes, low values of $\mathrm{CaO} \%$ are recorded in case of admixed mixes compared to $\mathrm{B}$ mix at all ages of hydration. Beside, increasing the percentage of RDF ash in OPC mixes from 5 to 10 wt.\% results to more decrease the $\mathrm{CaO} \%$ values. Besides, there are variations in the trend of increasing $\mathrm{CaO} \%$ with the ages of hydration in these admixed mixes. At early ages of hydration, up to 3 days, $\mathrm{CaO} \%$ values increased with the time of hydration. However at later ages of hydration, up to 28 days, $\mathrm{CaO} \%$ values may be decreased or remained unchanged while at 90 days increased. This variation in $\mathrm{CaO} \%$ values could be attributed to pozzolanic properties of RDF ash and their presence inside OPC matrix leads to their reaction with $\mathrm{Ca}(\mathrm{OH})_{2}$ and formation of additional amounts of calcium silicate hydrates, CSH. Such additional CSH precipitate inside the pore system of OPC pastes leading to lower porosity and improve mechanical properties. 


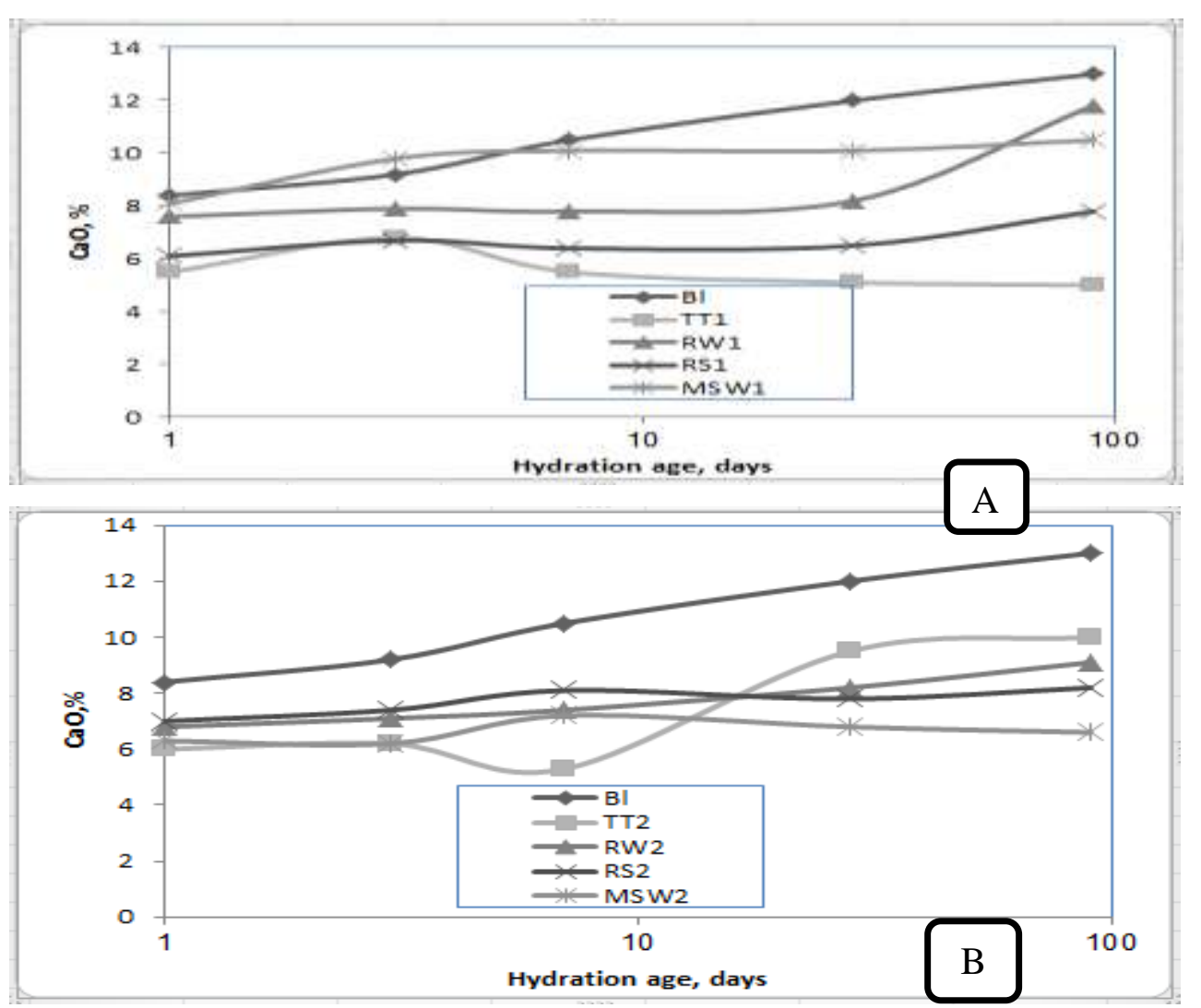

Fig.(6): Free lime contents (\%) o OPC pastes admixed with RD ashes a) 5 wt. $\%$ b) $10 \mathrm{wt}$.

\%TT1 5\% ash TT2 10\% ash RW1 5\% ash RW2 10\% RS1 5\% ash RS2 10\% MSW1 5\% ash MSW2 10\%

PHASE COMPOSTION: X-ray diffraction patterns of mixes B, TR2, RS2, RW2 and MT2 after 3 days of hydration are shown in Fig.5. XRD of blank mix, B, displays peaks which they are characterized to hydration products of OPC mainly; $\mathrm{Ca}(\mathrm{OH})_{2}(\mathrm{CH})$ and Calcium silicate hydrates $(\mathrm{CSH})$. The appearance o these peaks indicates the onset of the hydration reaction. Peaks 
due to unhydrated phases, $\mathrm{C}_{2} \mathrm{~S}, \mathrm{C}_{3} \mathrm{~S}$ and gypsum, are also identified in XRD of mix $\mathrm{B}$. The persistence of peaks due to $\mathrm{C}_{2} \mathrm{~S}$ and $\mathrm{C}_{3} \mathrm{~S}$ after 3 days of hydration is due to incomplete hydration reaction (El-Gamal, and Hashem, (2017). OPC pastes admixed with RDF ashes show the same hydration products as blank mix indicating that mixing of Portland cement with RDF ashes does not change the hydration phases. However the acceleration effect due to admixing of OPC with RDF ashes is clearly observed in XRD patters especially for mixes containing rubber ash (sample RW1) and municipal solid wastes (sample MSW1). There are distinct increases in intensity of peaks due to $\mathrm{CH}$ and $\mathrm{CSH}$ are noted accompanying the prevailing of peaks due to $\mathrm{C} 2 \mathrm{~S}$ and C3S with lower intensity than the case of mix B.

After 28 days of the hydration reaction, XRD patterns of the blank mix show an increase in the intensities of the peaks characterized to the hydration products, $\mathrm{CH}$ and $\mathrm{CSH}$, see Fig 6, this accompanied with a notable decrease in the intensities of reactants peaks. For OPC-ash mixes, again, no different hydration products are identified in their XRD patterns. However, the acceleration effect due to incorporated of RDF ashes in the hydrated matrix of OPC is nearly recovered as indicated by the similarity in the intensities of the peaks due to $\mathrm{CH}$ and $\mathrm{CSH}$ and those of the unhydrated phases as those of mix B. 


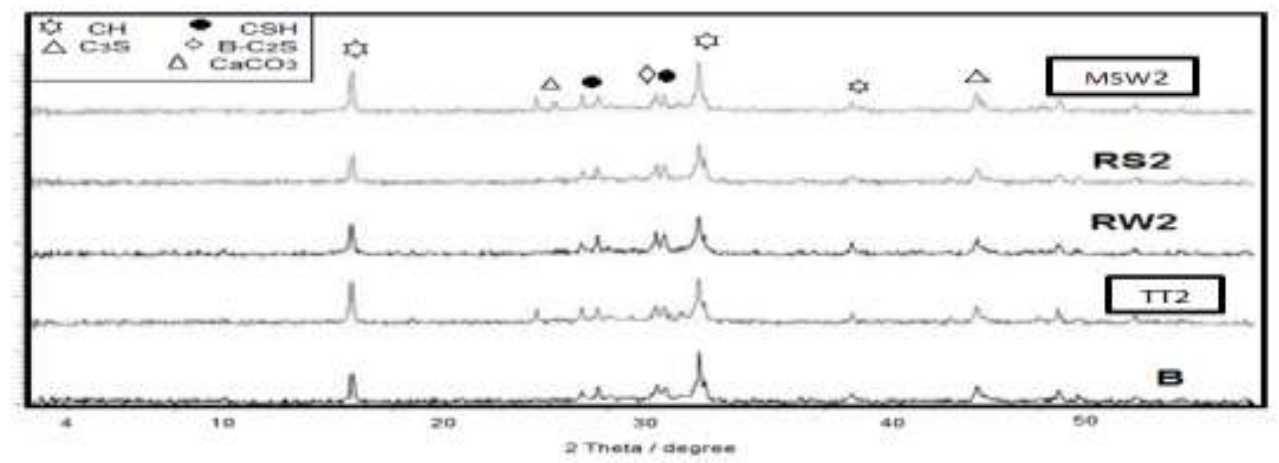

Fig.(7): XRD patterns of various mixes after 3 days of hydration

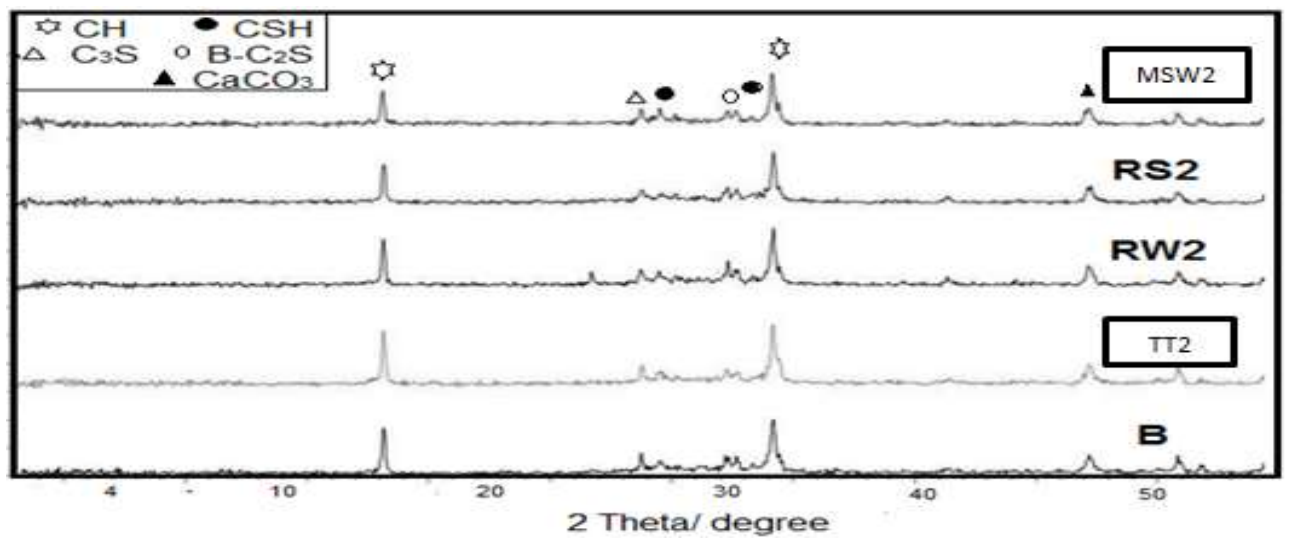

Fig. (8): XRD patterns of various mixes after 28 days of hydration. TT1 5\% ash TT2 10\% ash RW1 5\% ash RW2 10\% RS1 5\% ash RS2 10\% MSW1 5\% ash MSW2 1 
J. Environ. Sci.

Institute of Environmental Studies and Research - Ain Shams University

\section{CONCLUSION}

\section{On the basis of our studies the following conclusions could be derived:}

- Rubber waste, tree terminals, rice straw and mixed trash can be used as a source of RDF fuel for cement industry to replace the traditional fossil fuel.

- Rubber waste has the highest caloric value and density among the studied RDF sources.

- Mixing of the ash residue of these RDF sources with the cement clinker during manufacture lead to reduce the setting times and accelerate the early hydration reaction of the resultant cement.

- Mixing of OPC clinker with rubber waste ash increase the obtained compressive strength of OPC.

- Presence of RDF ash does not change the hydration mechanism of the produced cement.

\section{REFRENCES}

Abo-El-Enein, S.A.; Daimon, M.; Ohsawa, S. and Kondo, R (1972): "Hydration of low porosity slag-lime pastes", Cem. Concr. Res., 4, 299-312.

Abo-El-Enein, S.A.; Daimon, M.; Ohsawa, S. and Kondo, R.(1974): "Hydration of low porosity slag lime pastes", Cem. Concr. Res., 4, 299-312.

Abo-El-Enein, S.A.; Hashem, F.S.; Amin, M.S. and Sayed, D.M. (2016): "Physicochemical characteristics of cementitious building materials derived from industrial solid wastes", Constr. Build. Mater, 126, 983-990. 
Aldrian, A.; Sarc, R.; Pomberger, R.; Lorber, K.E. and Sipple, E.-M. ( 2016): "Solid recovered fuels in the cement industry-semi-automated sample preparation unit as a means for facilitated practical application", Waste Management \& Research, 34, 254-264.

Alter, M.; Ingle, G. and Kaiser, E.R. (1974): "Chemical Analysis of Organic Portions of Household Refuse; the Effect of Certain Elements on Incineration and Resource Recovery", Solid Waste Management, 64(10).

An Inventory of Sources and Environmental Releases of Dioxin-Like Compounds in the United States for the Years (1987), (1995), and (2000).

Bentz, D.P.; (2008). "A review of early-age properties of cement basedmaterials", Cem. Concr. Res., 38(2), 196-204.

Bisht, K. and Ramana, P.V. (2017): "Evaluation of mechanical and durability properties of crumb rubber concrete", Const. Build. Mater, 155(30), 811-817.

Bosoaga, A.; Masek, O. and Oakey, J.E. (2009): "CO2 capture Technologies for Cement Industry", Energy Procedia,1(1) 133-140.

Chatziaras, N.; Psomopoulos, C.S. and Themelis, N.J. (2014): "Use of alternative fuels in cement industry", Proceedings of the 12th International Conference on Protection and Restoration of the Environment.

Choy, K.K.H.; Ko, D.C.K.; Cheung, W.-H.; Fung, J.S.C.; Hui, D.C.W.; Porter, J.F. and Mckay. G. (2004): "Clean Technology and Waste Minimization Municipal Solid Waste Utilization for Integrated Cement Processing with Waste Minimization", Process Safety and Environmental Protection, 82(3), 200-207.

El-Gamal, S.M.A. and Hashem, F.S. (2017): "Enhancing the thermal resistance and mechanical properties of hardened Portland cement pastes by using pumice and A12O3", Journal of Thermal Analysis and Calorimetery, 128, 15-27 . 
El-Gamal, S.M.A.; Hashem, F.S. and Amin, M.S. (2012): "Thermal resistance of hardened cement pastes containing vermiculite and expanded vermiculite", J. Therm. Anal., 109, 217-226.

Garg, A.; Smith, R.; Hill, D.; Longhurst, P.J.; Pollard, S.J.T. and Simms, N.J. (2009): "An integrated appraisal of energy recovery options in the United Kingdom using solid recovered fuel derived from municipal solid waste", Waste Management, 29, 2289-2297.

Gendebien, A.; Leavens, A.; Blackmore, K.; Godley, A.; Lewin, K.; Whiting, K.J. and Davis, R. (2003): "Refused derived fuel, current practice and perspectives", European commission.

Girskas, G. and Nagrockiene, D. (2017): "Crushed rubber waste impact of concrete basic properties", Const. Build. Mater., 140 (1) June, 3642

Guo, Q. and Eckert, J.O.;(1996): "Heavy metal outputs from a cement kiln cofired with hazardous waste fuels", Journal of Hazardous Materials, 51(1-3), 47-65 Nov.

Kaantee, U.; Zevenhoven, R.; Backman, R. and Hupa, M. (2004):."Cement Manufacturing Using Alternative Fuels and the Advantages of Process Modelling", Fuel Processing Technology, 85, 293-301 .

Kaminskas, R.; Cesnauskas, V. and Kubiliute, R.(2015): "Influence of different artificial additives on Portland cement hydration and hardening", Constr. Build. Mater. 95(1) October, 537-544

Karstensen, K.H. (2008): "Formation, release and control of dioxins in cement kilns", Chemosphere, 70(4), 543-560 Jan.

Katare, V.D. and Madurwar, M.V.(2017): "Experimental characterization of sugarcane biomass ash - A review", Constr. Build. Mater. 152 (15) October, 1-15.

Kondo, R.; Abo-El-Enein, S.A. and Diamon, M. (1975): "Kinetics and mechanisms of hydrothermal reaction of granulated blast furnace slag", Bull. Chem. Soc., Jpn. 48, 222-226. 
Laszlo, S.; Hidalgo, I.; Ciscar, J.C. and Soria, A. (2006): "CO2 emission trading within the European union and annex B countries: the cement industry case", Energy Policy, 34(1), 72-87.190 .

Madlool, N.A.; Saidura, R.; Hossaina, M.S. and Rahim, N.A.(2011): "A critical review on energy use and savings in the cement industries", Renewable and Sustainable Energy Reviews, 15(4), 2042-2060.

Marland, G.; Boden, T.A. and Andres, R.J. (2008): "Global, Regional, and National Fossil Fuel CO2 Emissions. In Trends: A Compendium of Data on Global Change. Carbon Dioxide Information Analysis Center", Oak Ridge National Laboratory, U.S. Department of Energy, Oak Ridge, Tenn., U.S.A.

Martin, N.; Worrell, E. and Price, L (1990): "Energy efficiency and carbon dioxide emissions reduction opportunities in the US cement industry", Report No. LBNL-44182, Lawrence Berkeley National Laboratory, Berkeley, CA.

Marzouki, A.; Lecomte, A.; Beddey, A.; Diliberto, C. and Ben Ouezdou, M. (2013): "The effect of grinding on the properties of Portlandlimestone cement", Const. Build. Mater. 48, 1145-1155.

Mokrzycki, E.; Uliasz-Bochenczyk, A. and Sarna, M. (2003): "Use of Alternative Fuels in the Polish Cement Industry", Applied Energy, 74, 101-111.

Morsy, M.S.; Galal, A.F. and Abo-El-Enein, S.A. (1998): "Effect of temperature on phase composition and microstructure of artificial pozzolana-cement pastes containing burnt Kaolinite Clay", Cem. Concr. Res., 28 (8), 1157-1163.

Schwarzbock, T.; Aschenbrenner, P.; Rechberger, H.; Brandstatter, C. and Fellner, J.; (2016 a): "Effects of sample preparation on the accuracy of biomass content determination for refuse-derived fuels. Fuel Processing Technology 153:101-110. Technologies for cement industry", Energy Procedia, 1(1), 133-140. 
Seboka, Y.; Getahun, M.A. and Haile-Meskel, Y.; (2009): " Biomass Energy for Cement Production: Opportunities in Ethiopia. CDM Capacity Development in Eastern and Southern Africa", United Nations Development Programme.

Singhi, M.K. and Bhargava, R.; (2010): "Sustainable Indian cement industry", Workshop on International Comparison of Industrial Energy Efficiency, New Delhi, 27-28.

Spliethoff, H. and Hein, K.R.G.; (1998): "Effects of combustion of biomass on emissions in pulverized fuel furnaces", Fuel Processing Technology, 54, 189-205.

Zemba, S.; Ames, M.; Green, L.; Botelho, M.J. and Oliveira, J.P.; (2011): "Emissions of metals and polychlorinated dibenzo(p)dioxins and furans (PCDD/Fs) from Portland cement manufacturing plants: Inter-kiln variability and dependence on fuel types" Science of the Total Environment, 409(20) 4198-4205 .

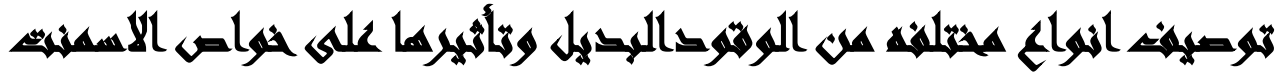

\section{$[r]$}

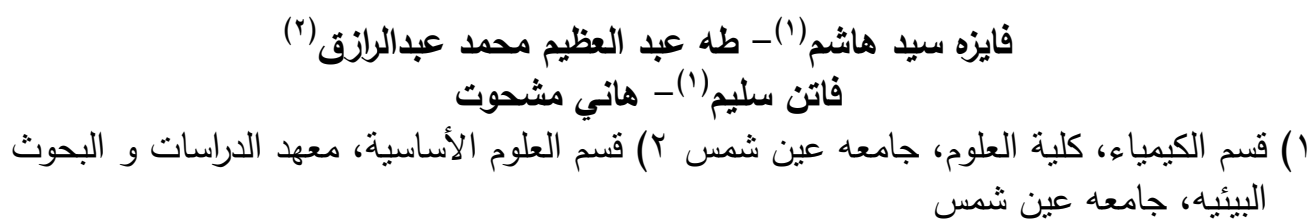

\section{المستخلص}

ازداد مؤخرا الطلب على استخدام الوقود المرفوض كبديل عن الوقود الاحفوري التقليدي في

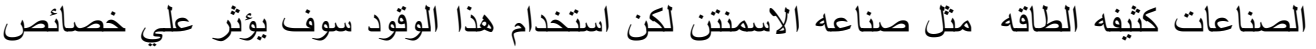

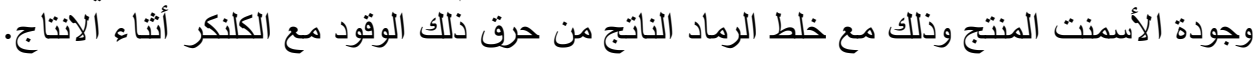

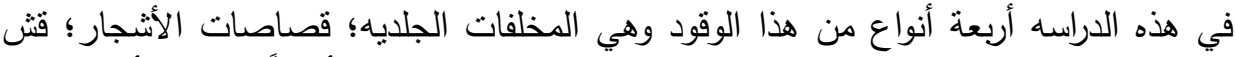

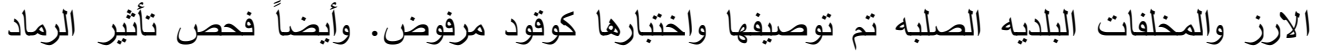
المتنقي في زمن الثنك وتصلب معجون الاسمنت البورتلاندي العادي.

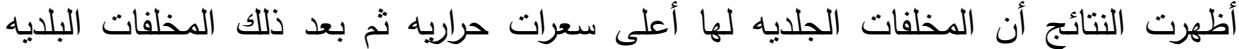

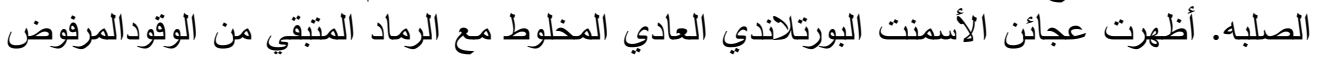


انخفاض زمن الثنك، كما ظهر أن الأسمنت البورتلاندي العادي المخلوط مع الرماد المتبقي من ألون

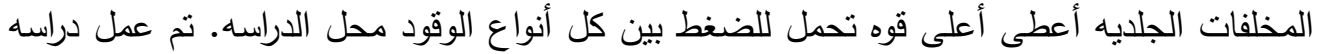

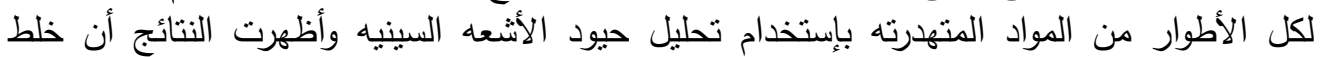
الأسمنت البورتلاندي العادي مع الرماد المتبقي لم يغير ميكانيكيه الهيدره حيث تكونت نفس الثن نواتج الهيدر.

كلمات مفتاحيه: الأسمنت البورتلاندي العادي؛ الوقود المتبقي: المخلفات الجلديه؛ المخلفات البلديه الصلبه؛(الطاقه. 